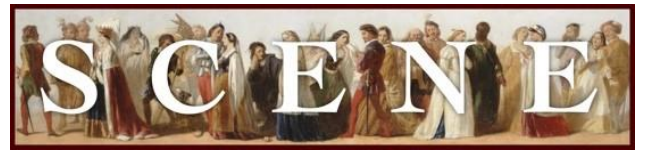

\title{
Movie Stars Make Much Ado in Bard on the Beach's Newest Adaptation
}

For the production: Much Ado About Nothing (2017, Bard on the Beach, Canada).

by Eve Preus. Written on 2017-06-20. Published in 2017 Issue 2.

Director John Murray's 2017 Bard on the Beach Production of Much Ado About Nothing is a savvy, sexy interpretation of Shakespeare's famous love story. Shakespeare's play follows the courtship rituals of two pairs of lovers who essentially represent two kinds of love: the idealized, romantic love of Hero and Claudio (played by Parmiss Sehat and Julien Galipeau) and the more modern, egalitarian love of Beatrice and Benedick (performed by Amber Lewis and Kevin MacDonald). Where Hero waits for and submits to Claudio's desire, Beatrice and Benedick wait for and pursue no one but themselves. The two are equals, competitors even, in love's disavowal. Benedick swears himself a bachelor for all time and Beatrice swears she will never be fitted with a husband until "God make men of some other metal than earth" (2.1.50-51). It is precisely their independence, their sharp minds, and their fierce self-possession that make them such a formidable love match. The battle of wits they stage in Much Ado About Nothing is consistently the most crowd-pleasing aspect of Shakespeare's comedy.

Murray's adaptation capitalizes on what he calls the "contemporary feel" of the romance between Beatrice and Benedick by making a few significant changes to Shakespeare's script. The first is to bring all the characters into the twentieth century-1959 to be exact. The second is to turn, as Murray's program notes reveal, "the soldiers and aristocrats into movie stars and filmmakers" and the set, which in the original is the home of Leonato the governor, into a movie studio owned by Leonato, now the famous head of a noted film studio. Indeed, all the characters get updated from early modern aristocrats to glamorous 1950 s movie stars and filmmakers.

In a play obsessed with its own theatricality, it's a clever move on Murray's part. Characters consistently fabricate stories about and for one another, and most of the plot is moved forward by reported speech: Benedick and Beatrice fall in love only through the play-acting machinations of their friends, and the major crisis of the play-Claudio witnessing Hero's 
supposed infidelity—is only ever spoken about, never performed for the live audience. By making Claudio, Hero, Benedick, and Beatrice movie stars, Don Pedro the famous movie director who scripts their romances, and the villain Dona Johnna a wannabe film-maker and paparazza who stages and frames the downfall of Hero, Murray makes explicit what is implicit in Shakespeare's play: these characters are all drama kings and queens, most at home gossiping and play-acting.

The time and setting adaptations were both inspired by Frederico Fellini's masterpiece La Dolce Vita, a film which is as much a critique of the hedonistic excess of the aristocracy as it is a meditation on the relative virtues of being married or staying unattached. You can tell these Italian movie stars in Much Ado, like their Vita prototypes, live a similarly "rarefied life, witty and urbane, with nothing to do but drink smoke and look incredibly elegant" (Murray). Costume designer Christine Reimer does a fine job dressing the women in black and white cocktail gowns with pearls, crystals, feathers, and splashes of blues and oranges, all signature colours and accouterments of the period. The men wear tailored suits with skinny ties in the evenings and trousers and polo shirts with sweaters tied around their necks during the day. And of course, every character has a pair of large black sunglasses in one hand and a lit cigarette in the other. The actors are clearly enjoying themselves as they parade across the stage in stilettos and wing tips, flippantly pulling out cigarette after cigarette, pouring themselves drinks, and singing along to Italian serenades. And we're enjoying it too. In one of my favourite such scenes-an improvised tango dance at Leonato's masquerade party between Benedick and Beatrice-Lewis and MacDonald absolutely light up the stage.

Inasmuch as La Dolce Vita lends the stylistic context and thematic relevance to Murray's adaptation of Much Ado About Nothing, I was left wondering just what all the slick glamour added up to in terms of the play's message of love. In Fellini's film, the protagonist Marcello Rubini is an ambitious and morally frail journalist-turned-gossip-columnist who ultimately chooses the "sweet life" of fashionable parties and gorgeous women over a respectable literary career and marriage to his loving fiancé. The film ends with a haunting and pervading sense of loneliness and alienation. In fact, the title La Dolce Vita has practically became synonymous with shallow, materialistic living, a life devoid of real love and sweetness.

But Shakespeare's play ends with the wedding of one couple and the promise of marriage of another, a testimony to the twin powers of true love and social order. Don Pedro, the only character left all alone during the nuptial celebrations, is told by Benedick to "get thee a wife, get thee a wife. There is no staff more reverend than one tipped with horn" (5.4.123-124). While the glitzy ostentation of celebrity culture in Vita served to reveal the disaffection at its core, it's 
unclear what the superstars of Messina will ultimately do with the narcissism at the heart of their celebrity now that they have found a love partner.

The question of love's mutuality is particularly germane to Beatrice and Benedick. In Shakespeare's play, Beatrice is a maid mostly because she is an orphan, unlikely to be married off as a commodity by a willing father. It is her wit that both staves off the loneliness of her fate and inspires the admiration of Benedick. In Murray's adaptation, however, she is an ambitious bombshell of a superstar, played to perfection by the sultry and irreverent Lewis. It's unclear exactly why Lewis's Beatrice needs or desires Benedick at all. Just how much of their wooing has been style over content, conquest over surrender? And if authentic, perhaps Beatrice's love for the man-child Benedick is a subtle gesture to the even more "contemporary feel" of the twentyfirst century professional woman: that special species of human who is told that she can do and have it all, only to find herself leagues above a dating pool full of men who, well, can't keep up. In the end, however, these feel like minor concerns. The cast and set of Bard's Much Ado About Nothing dazzle, and Murray's direction is energetic and exciting. Even through the slight chill of sitting in a tent for several hours on a rainy Vancouver evening, I left the theater tapping my feet. 